\title{
Regional nitrogen oxides emission trends in East Asia observed from space
}

\author{
B. Mijling ${ }^{1}$, R. J. van der $\mathbf{A}^{1}$, and Q. Zhang ${ }^{2}$ \\ ${ }^{1}$ Royal Netherlands Meteorological Institute (KNMI), Department of Climate Observations, P.O. Box 201, \\ 3730 AE De Bilt, the Netherlands \\ ${ }^{2}$ Center for Earth System Science, Tsinghua University, Beijing 100084, China
}

Correspondence to: B. Mijling (mijling@knmi.nl)

Received: 23 April 2013 - Published in Atmos. Chem. Phys. Discuss.: 3 July 2013

Revised: 16 October 2013 - Accepted: 1 November 2013 - Published: 11 December 2013

\begin{abstract}
Due to changing economic activity, emissions of air pollutants in East Asia are changing rapidly in space and time. Monthly emission estimates of nitrogen oxides derived from satellite observations provide valuable insight into the evolution of anthropogenic activity on a regional scale. We present the first results of a new emission estimation algorithm, specifically designed to use daily satellite observations of column concentrations for fast updates of emissions of short-lived atmospheric constituents on a mesoscopic scale $\left(\sim 0.25^{\circ} \times 0.25^{\circ}\right)$. The algorithm is used to construct a monthly $\mathrm{NO}_{\mathrm{x}}$ emission time series for the period 2007-2011 from tropospheric $\mathrm{NO}_{2}$ observations of GOME2 for East Chinese provinces and surrounding countries. The new emission estimates correspond well with the bottom-up inventory of EDGAR v4.2, but are smaller than the inventories of INTEX-B and MEIC. They reveal a strong positive trend during 2007-2011 for almost all Chinese provinces, related to the country's economic development. We find a $41 \%$ increment of $\mathrm{NO}_{\mathrm{x}}$ emissions in East China during this period, which shows the need to update emission inventories in this region on a regular basis. Negative emission trends are found in Japan and South Korea, which can be attributed to a combined effect of local environmental policy and global economic crises. Analysis of seasonal variation distinguishes between regions with dominant anthropogenic or biogenic emissions. For regions with a mixed anthropogenic and biogenic signature, the opposite seasonality can be used for an estimation of the separate emission contributions. Finally, the non-local concentration/emission relationships calculated by the algorithm are used to quantify the direct effect of regional $\mathrm{NO}_{\mathrm{x}}$ emissions on tropospheric $\mathrm{NO}_{2}$ concentrations outside
\end{abstract}

the region. For regions such as North Korea and the Beijing municipality, a substantial part of the tropospheric $\mathrm{NO}_{2}$ originates from emissions elsewhere.

\section{Introduction}

East Asia features some of the fastest changing economies of the world. Especially the Chinese economy grew rapidly over the past two decades. The unprecedented increase in energy demand, industrial production, urbanization and car ownership has resulted in significantly increasing air pollutant emissions. Being responsible for respiratory and cardiovascular problems, these high levels of air pollution affects the health of many people living in this region. Unfortunately, changes in emission strength and geographical pattern are not adequately described by bottom-up emission inventories. They are easily outdated, despite the sustained efforts to provide complete and accurate databases. Satellite observations of air pollutants have a high temporal resolution, they are spatially consistent, and are rapidly available. Emission estimates based on observations of short-living species as $\mathrm{NO}_{2}, \mathrm{SO}_{2}$ and $\mathrm{PM}$ allow for the monitoring of emission trends, giving important insight in the environmental impact of socio-economic events and the effectiveness of air quality policy.

For $\mathrm{SO}_{2}$, the most important sources are point sources by power plants and heavy industry. $\mathrm{Li}$ et al. (2010) finds that the $\mathrm{SO}_{2}$ trend is in line with the $\mathrm{NO}_{2}$ trend during the period 2005-2007. Afterwards, however, a sharp drop is observable from spaceborne observations, due to installation of flue gas 
desulphurisation devices on power plants and phasing out of small power generating units. The Chinese Ministry of Environmental Protection reported a $9 \%$ reduction of total $\mathrm{SO}_{2}$ emissions for the period 2005-2009 (Li et al., 2010).

Based on aerosol optical depth data from OMI, Lin and McElroy (2011) saw a rapid growth of $\mathrm{PM}_{2.5}$ concentrations over northeast China from October 2004 to September 2008, despite national efforts to control emissions of primary PM and $\mathrm{SO}_{2}$. The growth is attributed to increased formation of secondary aerosols by increased emissions of precursors such as $\mathrm{NH}_{3}$, volatile organic compounds, and - most importantly $-\mathrm{NO}_{\mathrm{x}}$.

The total Chinese emissions of anthropogenic $\mathrm{NO}_{\mathrm{x}}$ showed an increase from $3.8 \mathrm{Tg} \mathrm{Nyr}^{-1}$ in 2000 (Zhang et al., 2007) to $6.3 \mathrm{Tg} \mathrm{N} \mathrm{yr}^{-1}$ in 2006 (Zhang et al., 2009a). The economic downturn, which affected Chinese economy between late 2008 and late 2009, caused a decrease in emissions of $20 \%$ when comparing January 2008 with January 2009 (Lin and McElroy, 2011), although $11 \%$ might be attributed to a production slowdown related to the Chinese New Year. The air quality measures in preparation for the Beijing Olympic Games resulted in an emissions drop of 45$50 \%$ in Beijing when compared with the emissions in the months before the event (Mijling et al., 2009; Mijling and van der A, 2012). For the World Expo 2010 in Shanghai air quality measures were also taken, which, according to Hao et al. (2011), resulted in a decrease of $8 \%$ of $\mathrm{NO}_{2}$ over the city from May to October 2010 when compared to mean $\mathrm{NO}_{2}$ concentrations of the same period in the three previous years.

In this study, we use the Daily Emission estimates Constrained by Satellite Observations (DECSO) algorithm to construct monthly $\mathrm{NO}_{\mathrm{x}}$ emission estimates for East Asia based on GOME-2 observations of tropospheric $\mathrm{NO}_{2}$ between 2007 and 2011. The yearly emission totals for East China are compared with other satellite-derived estimates and bottom-up inventories in Sect. 3. The relatively high resolution of the emission estimates enables us to assess the evolution of $\mathrm{NO}_{\mathrm{x}}$ emissions of individual Chinese provinces and peripheral countries. Applying a trend model to the monthly emission time series reveals regional differences in emission trends (Sect. 4.1) and seasonalities (Sect. 4.2). In Sect. 5, the non-local concentration/emission relationships are used to quantify the transport effect of regional $\mathrm{NO}_{\mathrm{x}}$ emissions on tropospheric $\mathrm{NO}_{2}$ concentrations elsewhere.

\section{The DECSO algorithm applied to East Asia}

The DECSO algorithm (Mijling and van der A, 2012) is specifically designed to use daily satellite observations of column concentrations for fast updates of emission estimates of short-lived atmospheric constituents on a mesoscopic scale $\left(0.25^{\circ} \times 0.25^{\circ}\right)$. Central in the algorithm is the approximation of the sensitivity $H_{i j}$ of a, $\mathrm{NO}_{2}$ column concentration $c$ in grid cell $i$ on the mean emission $e$ in grid cell $j$ :

$\mathbf{H}_{i j}=\frac{\mathrm{d} c_{i}^{\mathrm{NO}_{2}}}{\mathrm{~d} e_{j}^{\mathrm{NO}_{x}}}=\gamma_{i} \frac{a_{j}}{a_{i}} \int_{0}^{T} \exp \left(-(T-t) / \tau_{j}\right) \Omega_{i j}(t) f_{j}(t) \mathrm{d} t$

The integral is taken over a time window $(0, T)$ between two satellite overpasses $(24 \mathrm{~h}) . \Omega_{i j}(t)$ describes the transport of $\mathrm{NO}_{\mathrm{x}}$ from cell $j$ to $i$ during $(t, T)$, based on trajectory analysis. After emission, $\mathrm{NO}_{\mathrm{x}}$ is decayed with an effective lifetime $\tau_{j}$. Modulation factor $f_{j}(t)$ relates the time-dependent emissions $e(t)$ to the daily averaged emission $e: e(t)=f(t) e$. The factor $a_{j} / a_{i}$ accounts for the ratio in grid cell area, and $\gamma_{j}$ represents the $\mathrm{NO}_{2} / \mathrm{NO}_{\mathrm{x}}$ ratio. Lifetime $\tau_{j}$ is found by minimizing the difference at $t=T$ between the $\mathrm{NO}_{\mathrm{x}}$ columns of the chemical transport model (CTM) and the $\mathrm{NO}_{\mathrm{x}}$ columns calculated with the transport kernel $\Omega$. The sensitivities $\mathbf{H}$ are interpolated to the satellite footprints and are corrected for by the averaging kernel of the retrieval method. A detailed description can be found in Mijling and van der A (2012). For short-lived species such as $\mathrm{NO}_{\mathrm{x}}, \mathbf{H}$ is a sparse matrix, facilitating a fast calculation of the inversion by data assimilation.

We use the DECSO algorithm together with the regional CTM CHIMERE (Schmidt et al., 2001; Bessagnet et al., 2004), driven by operational meteorological forecast of the European Centre for Medium-Range Weather Forecasts (ECWMF). The CTM is adjusted for application on a $0.25^{\circ}$ resolution covering East Asia from 18 to $50^{\circ} \mathrm{N}$ and 102 to $132^{\circ} \mathrm{E}$, as described in more detail by Mijling et al. (2009). Apart from East China, the domain contains North and South Korea, the Japanese island of Kyushu, and significant parts of Mongolia and Vietnam. The model is driven by meteorological data of the European Centre for Medium-Range Weather Forecasts (ECMWF). The initial anthropogenic emissions are taken from the 2006 INTEX-B inventory (Zhang et al., 2009a).

We use $\mathrm{NO}_{2}$ observations from the GOME-2 instrument, carried on the MetOp-A satellite which was launched in October 2006. Tropospheric $\mathrm{NO}_{2}$ column retrievals are calculated with the DOMINO v2 algorithm (Boersma et al., 2011) from spectral measurements between $426-451 \mathrm{~nm}$. Cloud fraction and cloud height are derived from the oxygen-A band (Koelemeijer et al., 2001). $\mathrm{NO}_{2}$ retrievals at cloud fractions larger than $20 \%$ are filtered out to reduce the influence of the modelled $\mathrm{NO}_{2}$ column below the clouds. Retrievals with low clouds (below $800 \mathrm{hPa}$ ) are also rejected because the intersection of the cloud with the $\mathrm{NO}_{\mathrm{x}}$ bulk makes the retrieval too sensitive for the exact cloud height. Typically, the tropospheric $\mathrm{NO}_{2}$ columns have a dominating absolute error of $0.510^{15} \mathrm{molec} \mathrm{cm}^{-2}$ at low values, and a dominating relative error of $40 \%$ at high values. The GOME- 2 retrievals correspond well with MAX-DOAS observations in China and Japan as reported by Irie et al. (2012).

To compare the model simulations with the satellite observations, we first extend the CHIMERE vertical profiles from the model ceiling (at $500 \mathrm{hPa}$ ) to the tropopause with 
a climatological partial column. The profiles are then interpolated to the observational footprints (having a lower spatial resolution), after which the averaging kernel can be directly applied (see Mijling and van der A, 2012).

Having more emission grid cells than daily concentration observations, the inversion is underdetermined. We use a Kalman filter to regulate this problem. At each analysis stage, the new emission estimation is a combination of the true emission and the previous emission estimation. The strength of the coupling to the true emissions depends on the the Kalman gain (determined by the balance of the errors in the observation and the model) and the sensitivity (the relation between the emission and the observable concentration). The weak coupling we have in our inversion setting means that the emission estimations have a certain response time to new emission levels. This results in a spin-up time for the whole system to stabilize from the initial NOx emission inventory, which in our setting is estimated to be at most 3 months.

With the DECSO algorithm, a data set of $\mathrm{NO}_{\mathrm{x}}$ emission estimates on the model grid is compiled for 2007 to 2011, based on daily inversion of GOME-2 observations (typically 500-900 every day after filtering). The emissions have been monthly averaged over the provincial areas to avoid issues related to regional undersampling, and to improve noise characteristics. Note that the size of the GOME2 foot print $\left(\sim 40 \times 80 \mathrm{~km}^{2}\right)$ is smaller than the smallest provinces Shanghai $\left(6430 \mathrm{~km}^{2}\right)$, Tianjin $\left(11305 \mathrm{~km}^{2}\right)$, Beijing $\left(16800 \mathrm{~km}^{2}\right)$, and Hainan $\left(34000 \mathrm{~km}^{2}\right)$. However, emissions close to the provincial borders can be affected by the spatial detection resolution of the method and be partly attributed to neighbouring provinces.

The quality of the estimated emissions depends on the quality of the satellite observation, the model simulation and the inversion scheme. Lin et al. (2012b) show that modelled $\mathrm{NO}_{2}$ columns are sensitive to several parameters, especially to the correct cloud optical depth, the uptake rate of $\mathrm{HO}_{2}$ on aerosols, and the rate constant for the reaction between $\mathrm{OH}$ and $\mathrm{NO}_{2}$. In their setting (GEOS-Chem simulations at OMI overpass time), $\mathrm{NO}_{2}$ emissions can be overestimated by $8 \%$ (in winter) to $18 \%$ (in summer), due to underestimated $\mathrm{NO}_{2}$ column simulations. It is unclear, however, how these results translate to our set-up (an elaborate bias analysis will be a subject for future study). A positive emission bias during summer is plausible, as CHIMERE also underestimates the $\mathrm{NO}_{2}$ column in summer with respect to OMI (Huijnen et al., 2010). However, the earlier overpass time of GOME-2 might reduce this effect due to less active photochemistry in the morning.

\section{Comparison of DECSO $\mathrm{NO}_{\mathrm{x}}$ estimates with other inventories}

The model domain (shown in Fig. 1) covers completely or partially 28 provinces of mainland China, which according to the EDGAR v4.2 inventory (EC-JRC/PBL, 2011) accounts for approximately $94 \%$ of the total Chinese anthropogenic emissions.

The yearly $\mathrm{NO}_{\mathrm{x}}$ emission totals for this part of China by the DECSO algorithm grew from 5.63 $\mathrm{Tg} \mathrm{N} \mathrm{yr}^{-1}$ in 2007 to $7.96 \mathrm{Tg} \mathrm{N} \mathrm{yr}^{-1}$ in 2011. Other space-derived emission estimates found in literature are listed in Table 1. Direct comparison, however, is troubled by the different periods and regions which are considered. Miyazaki et al. (2012) found 5.0 $\mathrm{Tg} \mathrm{N} \mathrm{yr}^{-1}$ for East China in 2005, for a 4-month mean of January, April, June, and October. They assimilated OMI observations into the CHASER model using an ensemble Kalman filter approach. Stavrakou et al. (2008) constructed an emission time series with the IMAGES CTM and its adjoint code, based on a combined record of GOME and SCIAMACHY observations between 1997 and 2006. Total Chinese emissions in 1997 were found to be $3.33 \mathrm{Tg} \mathrm{N} \mathrm{yr}^{-1}$, with an annual growth rate of $7.3 \% \mathrm{yr}^{-1}$, which results in $5.52 \mathrm{Tg} \mathrm{N} \mathrm{yr}^{-1}$ for China in 2006. Lin (2012a) used OMI retrievals for 2006 together with the GEOS-Chem model. $\mathrm{He}$ estimated the emissions to be $7.06 \mathrm{Tg} \mathrm{Nyr}^{-1}$ for anthropogenic sources in East China in 2006. However, this number might be overestimated by $8-18 \%$ due to errors in the model simulations (Lin et al., 2012b). Zhao and Wang (2009) found 7.48 $\mathrm{Tg} \mathrm{N} \mathrm{yr}^{-1}$ for fossil fuel emissions in China (6.78 $\mathrm{Tg} \mathrm{N} \mathrm{yr}^{-1}$ for East China) in July 2007, based on local inversion of OMI observations using the method by Martin et al. (2003) in combination with the REAM CTM. Lin et al. (2010b) used the difference in overpass time between GOME-2 and OMI to estimate $\mathrm{NO}_{\mathrm{x}}$ emissions. For July 2008, they found as best estimate $6.8 \mathrm{Tg} \mathrm{N} \mathrm{yr}^{-1}$ for China, and $5.5 \mathrm{TgN} \mathrm{yr}^{-1}$ for East China $\left(103.75-123.75^{\circ} \mathrm{E}\right.$; $\left.19-45^{\circ} \mathrm{N}\right)$.

The yearly emission totals by DECSO emission estimates have been compared with the bottom-up inventories INTEXB (Zhang et al., 2009a), MEIC, EDGAR v4.2, and REAS v1.1 (Ohara et al., 2007). The regional INTEX-B inventory contains Asian emissions in 2006 on a $0.2^{\circ}$ resolution divided over the sectors power, industry, transport, and residential. In this study, it is also used as initial emission inventory for the DECSO algorithm. The MEIC inventory developed by Tsinghua University contains monthly emissions for China, and is available on a $0.25^{\circ}$ resolution for 2008 and 2010 through http://www.meicmodel.org. MEIC does not contain emission information outside China. The global EDGAR v4.2 inventory contains yearly emission totals for the period 1970 to 2008 on a $0.1^{\circ}$ resolution. Only the last two years (referred to as EDGAR 2007 and EDGAR 2008) are of interest for comparison with the DECSO estimates. The REAS inventory describes emissions in Asia on a $0.5^{\circ}$ resolution. It uses 2000 as a base year from which projections for 2004-2009 are made. Of the three available emission scenarios in 2010 we used the worst-case scenario, containing the highest emission rates of $\mathrm{NO}_{\mathrm{x}}$. 
The bottom-up inventories cover only anthropogenic emissions, whereas the DECSO emission totals include both anthropogenic and biogenic sources. However, due to strong industrial activity, $\mathrm{NO}_{\mathrm{x}}$ emissions in East China are predominantly anthropogenic. Lin (2012a) estimate that biogenic emissions of lightning and soil account for less than $6 \%$ of the total emissions in East China, annually. In July, when lightning and soil emissions are most dominant, a contribution of $9 \%$ and $12 \%$ respectively of total emissions is found. Areas with important biogenic sources are mostly found in Inner Mongolia and West China. Anthropogenic emissions are largest in cities and areas with extensive use of coal.

As can be seen in Table 2, there is reasonable agreement between the EDGAR 2007 and EDGAR $2008 \mathrm{NO}_{\mathrm{x}}$ inventory with the corresponding estimates from space by the DECSO algorithm, which gives confidence in the results. However, the DECSO estimates are significantly smaller than the $\mathrm{NO}_{\mathrm{x}}$ inventories of INTEX-B and MEIC. On the other hand, the DECSO emissions are larger than the projected REAS emissions. Apparently, the REAS scenarios underestimate the development of $\mathrm{NO}_{\mathrm{x}}$ emissions in East China. According to the DECSO estimates, the $\mathrm{NO}_{\mathrm{x}}$ emission estimates for East China increased by $41 \%$ between 2007 and 2011, which shows the need for regular updates of East Asian emission inventories.

Figure 2 shows the comparison between the different inventories for economically important Chinese provinces and some neighbouring countries. In general, a reasonable agreement is found between the MEIC inventory and DECSO. Some areas with strong differences will be discussed. Emissions in Guangdong (the province with the largest population and having the highest gross domestic product in China) are estimated higher by both MEIC and EDGAR for the years 2008 and 2010. On the other hand, emissions in Shaanxi are estimated lower by both MEIC and EDGAR. Due to its large coal deposit, industry in Shaanxi is centred around heavy industries such as power generation and metal refining. The emission differences might originate from industrial activity, which is unaccounted for in the bottom-up inventories. In Mongolia, the DECSO estimates are significant larger than EDGAR. This is however partly due to the fact that DECSO estimates include biogenic emissions, which in Mongolia are of importance (see Sect. 4.2), but are not accounted for in the bottom-up anthropogenic inventory.

\section{Emission time series analysis}

Analogous to the trend analysis of $\mathrm{NO}_{2}$ concentrations by van der A et al. (2006, 2008), we describe the monthly DECSO $\mathrm{NO}_{\mathrm{x}}$ emission time series $E(t)$ with a trend model which contains a linear trend and a seasonal cycle:

$E(t)=E_{0}+\frac{1}{12} B t+A \sin (\omega t+\phi)+r(t)$, where $t$ represents the number of months after January 2007, $r(t)$ is the residue (the part of the emission that is unexplained by the fit function). $E_{0}, B, A, \phi$ are the fit parameters of the model. The angular frequency $\omega$ is taken $\pi / 6$, representing a periodicity of one year. $E_{0}$ is the emission offset, $B$ is the annual trend in emissions, $A$ is the amplitude of the seasonal cycle, $\phi$ is the phase of the seasonality ( $\phi=0$ corresponding to a maximum in January, $\phi=\pi / 6$ corresponding to a maximum in July). In the regression, the absolute error on the monthly estimates is taken a constant value $\sigma$ (taken $10 \%$ of the mean value of the time series). To compensate for the spin-up error of the algorithm due to wrong initial emissions, we increase the error to $3 \sigma$ for January 2007, and decrease the error linearly to $\sigma$ in the 4 following months.

From the fit parameters the fitted mean emission for base year 2007 can be calculated: $E_{2007}=E_{0}+11 / 24 B$. Relative emission trends are calculated with respect to this mean emission in 2007.

\subsection{Linear trend in $\mathrm{NO}_{\mathrm{x}}$ emissions}

The linear trend results for the East Chinese provinces and peripheral countries are shown in Fig. 3. The largest $\mathrm{NO}_{\mathrm{x}}$ emitting provinces are clustered in northeast China: Shandong (606 Gg N yr${ }^{-1}$ ), Jiangsu ( $431 \mathrm{Gg} \mathrm{N} \mathrm{yr}^{-1}$ ), Shaanxi (423 $\mathrm{Gg} \mathrm{Nyr}^{-1}$ ), Hebei $\left(395 \mathrm{Gg} \mathrm{N} \mathrm{yr}^{-1}\right.$ ), followed by Guangdong $\left(361 \mathrm{Gg} \mathrm{N} \mathrm{yr}^{-1}\right.$ ) in south China.

All provinces of mainland China show positive trends for the 2007-2011 period. In an absolute sense, the strongest increase of $\mathrm{NO}_{\mathrm{x}}$ emissions are found in Hebei $\left(91 \mathrm{Gg} \mathrm{N} \mathrm{yr}^{-2}\right)$, Shandong $\left(77 \mathrm{Gg} \mathrm{Nyr}^{-2}\right)$, Inner Mongolia $\left(55 \mathrm{Gg} \mathrm{Nyr}^{-2}\right.$ ), and Henan (44 $\left.\mathrm{Gg} \mathrm{Nyr}^{-2}\right)$. $\mathrm{NO}_{\mathrm{x}}$ emission growth rates over $20 \%$ are found for Shaanxi $\left(24.6 \% \mathrm{yr}^{-1}\right)$, Hebei $\left(23.2 \% \mathrm{yr}^{-1}\right)$, Hainan $\left(22.5 \% \mathrm{yr}^{-1}\right)$, and Sichuan $\left(21.8 \% \mathrm{yr}^{-1}\right)$. The strong relative emission growth in peripheral provinces might reflect that they are catching up economically with the richer areas of China. In a relative sense, the strongest increase of $\mathrm{NO}_{\mathrm{x}}$ emissions is found in East Mongolia $\left(24.7 \% \mathrm{yr}^{-1}\right)$.

The linear trend model does not work well for Beijing, due to the trend break during the Olympic Games in 2008 (see Sect. 5.3). The absolute emission trend for the entire 20072011 period is $9 \mathrm{Gg} \mathrm{N} \mathrm{yr}^{-2}$, but is in fact higher for the last three years.

Shanghai has the largest $\mathrm{NO}_{\mathrm{x}}$ emission flux of all Chinese provinces: it is estimated to be $8.8 \times 10^{15}$ molecules $\mathrm{cm}^{-2} \mathrm{~h}^{-1}$ in 2007. Between 2007 and 2010 its population increased from 18 to 23 million inhabitants, and private car ownership increased from 2 million in 2004 to 3.1 million in 2010 (Chen and Zhao, 2013). However, Shanghai does not show a significant emission trend. One of the reasons for this atypical disagreement between growth and emissions might be the effectiveness of local air quality measures, such as vehicle emission control and the migration 

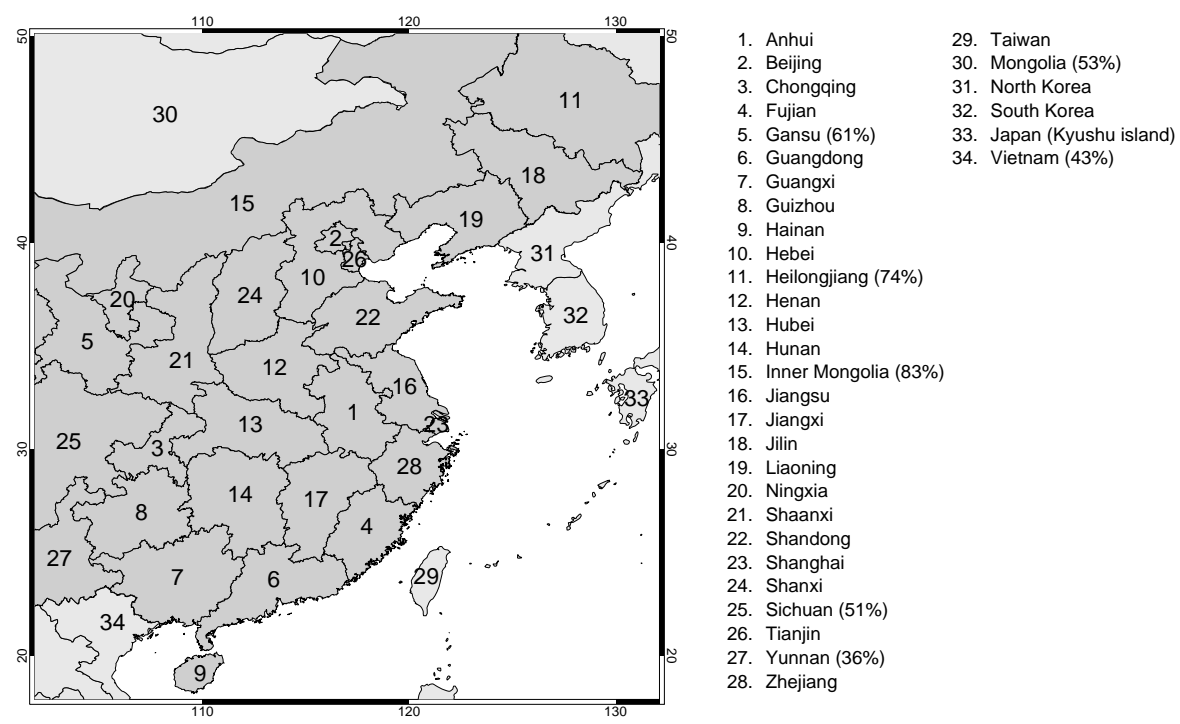

Fig. 1. Chinese provinces and surrounding countries that are covered by the model domain. Between parentheses, the fraction of the area within the domain is indicated.

Table 1. Overview of satellite-derived $\mathrm{NO}_{\mathrm{x}}$ emission estimates for China for recent years found in literature.

\begin{tabular}{llll}
\hline Study & Emissions $\left(\mathrm{Tg} \mathrm{N} \mathrm{yr}^{-\mathbf{1}}\right)$ & Period & Data / Model \\
\hline Miyazaki et al. (2012) & 5.0 (East China) & 2005 (Jan, Apr, Jun, Oct) & OMI / CHASER \\
Stavrakou et al. (2008) & 5.52 (China) & 2006 & GOME + SCIAMACHY / IMAGES \\
Lin (2012a) & $7.06^{*}$ (East China) & 2006 & OMI / GEOS-Chem \\
Zhao and Wang (2009) & 7.48 (China) 6.78 (East China) & 2007 (Jul) & OMI / REAM \\
Lin et al. (2010b) & 6.8 (China) 5.5 (East China) & 2008 (Jul) & GOME-2 + OMI \\
\hline
\end{tabular}

* Possibly overestimated by $8-18 \%$ due to model errors (Lin et al., 2012b).

Table 2. Comparison of yearly $\mathrm{NO}_{\mathrm{x}}$ emission totals for East China (18-50 ${ }^{\circ} \mathrm{N}$ and $102-132^{\circ} \mathrm{E}$; see Fig. 1) in $\mathrm{Tg} \mathrm{N} \mathrm{yr}^{-1}$.

\begin{tabular}{lrrrrrr}
\hline & 2006 & 2007 & 2008 & 2009 & 2010 & 2011 \\
\hline DECSO & - & 5.63 & 5.91 & 6.06 & 7.09 & 7.96 \\
EDGAR v4.2 & 5.03 & 5.34 & 5.93 & - & - & - \\
INTEX-B & 6.09 & - & - & - & - & - \\
MEIC & 6.75 & 7.28 & 7.59 & 7.74 & 8.33 & - \\
REAS v1 & 4.44 & 4.55 & 4.65 & 4.76 & 4.86 & - \\
\hline
\end{tabular}

of coal-fired power plants away from the metropolitan area (Wang et al., 2012).

$\mathrm{NO}_{\mathrm{x}}$ emissions in Inner Mongolia are dominated by power plants and heavy industry. Inner Mongolia is a developing province with the highest coal reserve of any province in China. In 2006, $55 \%$ of the total $\mathrm{NO}_{\mathrm{x}}$ emissions originated from power plants, which are often built close to the coal resource (Zhang, 2009b). Between 2005 and 2007 an additional $18.6 \mathrm{GW}$ electricity production from coal-fired power plants was installed in Inner Mongolia, which increased the
$\mathrm{NO}_{\mathrm{x}}$ emissions by power plants by $51 \%$ in this province (Wang et al., 2012).

Negative trends are found for the Japanese island of Kyushu $\left(-5.6 \% \mathrm{yr}^{-1}\right)$, for South Korea $\left(-2.2 \% \mathrm{yr}^{-1}\right)$, and for Taiwan $\left(-2.1 \% \mathrm{yr}^{-1}\right)$. These trends can be attributed to a combined effect of local environmental policy and global economic crisis since 2008.

\subsection{Seasonal variability of $\mathrm{NO}_{\mathrm{x}}$ emissions}

In most regions a distinct seasonal cycle in $\mathrm{NO}_{\mathrm{x}}$ emissions is found, as is illustrated in Fig. 4. This variability can be used to derive more information about the dominant emission source. van der A et al. (2006) showed that anthropogenic sources cause $\mathrm{NO}_{2}$ concentrations to peak in wintertime, while soil emissions peak in summertime. Biomass burning is an unimportant source of $\mathrm{NO}_{\mathrm{x}}$ in East China (Wang et al., 2007), contributing less than $2 \%$ to the total emissions.

In regions with dominant anthropogenic emissions, such as Hebei and Shandong, we find that emissions peak typically in February-March. Anthropogenic emission totals in the MEIC inventory typically peak in January as is expected, 

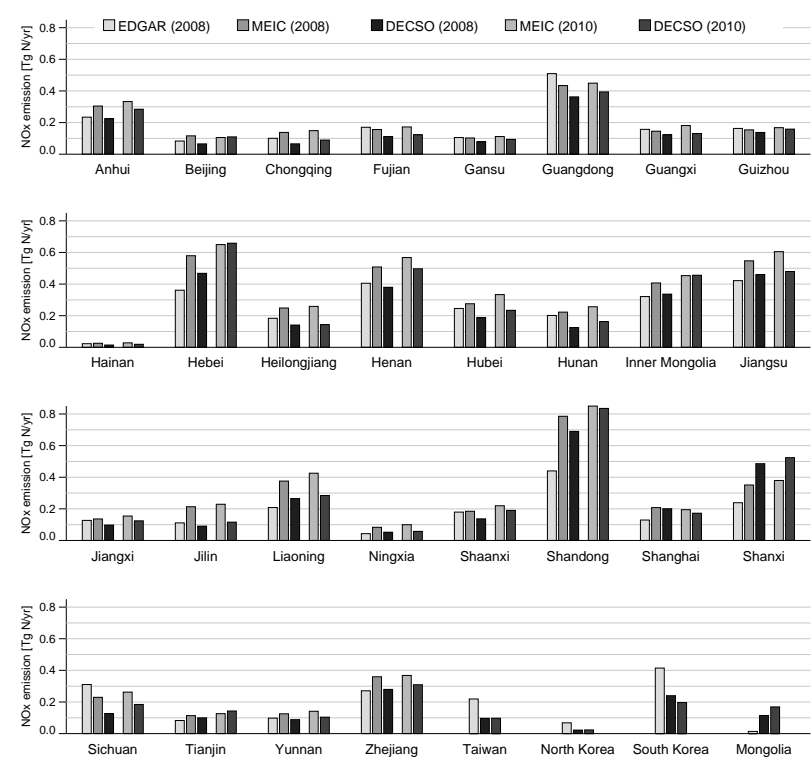

Fig. 2. Comparison of bottom-up inventories EDGAR v4.2 (2008) and MEIC (2008, 2010) with yearly averaged emission estimates by the DECSO algorithm for different Chinese provinces and countries. (a) $\mathrm{NO}_{\mathrm{x}}$ emissions in 2007

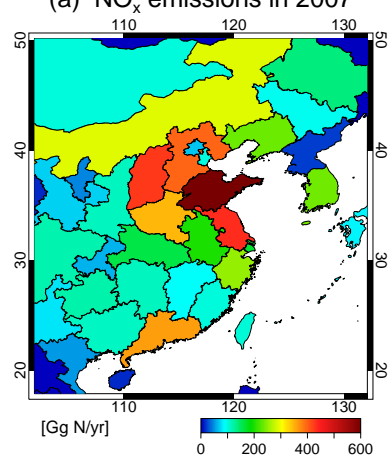

(c) Emission trend

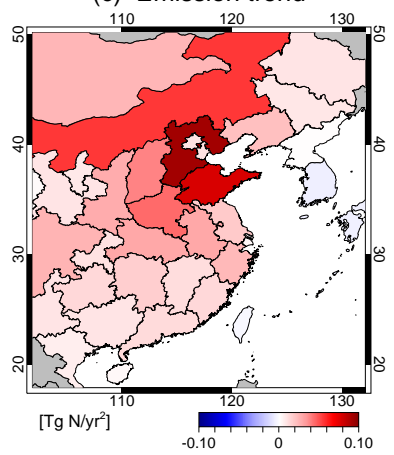

(b) Emission fluxes in 2007

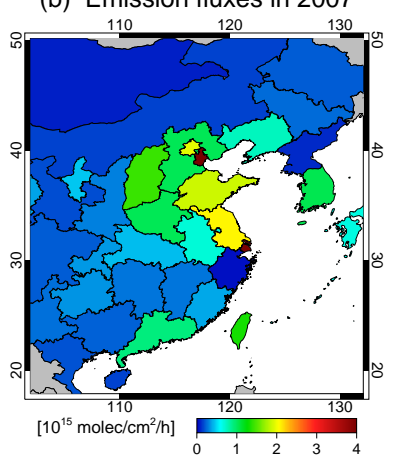

(d) Relative emission trend

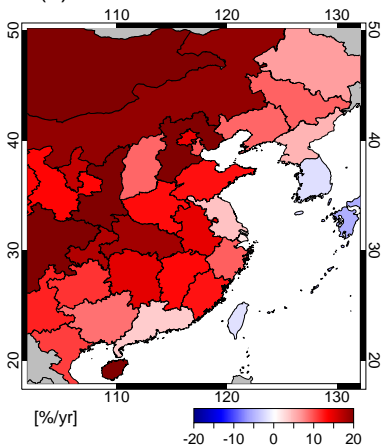

Fig. 3. (a) Total $\mathrm{NO}_{\mathrm{x}}$ emissions in 2007 per region, as fitted by the trend model. (b) Emissions per unit area per region. (c) Annual trends in total $\mathrm{NO}_{\mathrm{x}}$ emission per region for the 2007-2011 period. (d) Relative trends for regional $\mathrm{NO}_{\mathrm{x}}$ emissions. which might indicate that our method introduces a time lag of about 1 month in its response to emission changes.

This time lag can be explained by the response time from the Kalman filter to the periodic seasonal signal. For a certain coupling strength to the true emissions (see Sect. 2), the time lag depends on the sampling frequency of the signal. The Kalman filter acts as a low-pass filter: a higher frequency lowers the amplitude of the response. Emissions maxima will therefore be slightly underestimated (as emission minima will be overestimated), but yearly averaged emissions and the observed linear trend are not affected.

Important natural emissions (i.e. soil and lightning emissions) are found in e.g. Mongolia, where grasslands dominate $97 \%$ of the country. Natural emissions of $\mathrm{NO}_{\mathrm{x}}$ are related to the rainy season: $70-80 \%$ of the annual precipitation falls as rain in the summer season, with a maximum in August (Iwasaki, 2005). Again, a time delay of about one month in the observed seasonal emission peaks (September 2007, August 2008, September 2009, September 2010, September 2011) is observed. The underlying linear trend in Mongolia is associated to increasing anthropogenic emissions.

In Inner Mongolia, both anthropogenic and natural sources are of importance. The positive linear trend $\left(19.1 \% \mathrm{yr}^{-1}\right)$ is most probably due to increased anthropogenic emissions by coal-fired power plants and related heavy industry (Zhang et al., 2009b). The lack of a strong seasonal cycle can be explained by the trend being a mixed signal of anthropogenic and natural emissions. The opposite seasonality of these sources can be used for a rough estimate of the separate anthropogenic emissions and natural emissions. Using Eq. (2), we can write anthropogenic emissions $E^{a}$ as

$E^{a}=E_{0}^{a}+\frac{1}{12} B^{a} t+A^{a} \cos \omega t$.

The natural emissions $E^{b}$ can be written as

$E^{b}=E_{0}^{b}(1-\cos \omega t)$,

assuming that they are perfectly anti-cyclic with anthropogenic emissions, that they have no trend, and that there are no emissions in winter. The yearly averaged natural emission is $E_{0}^{b}$. The total emission $E$ can now be written as

$E=\left(E_{0}^{a}+E_{0}^{b}\right)+\frac{1}{12} B^{a} t+\left(A^{a}-E_{0}^{b}\right) \cos \omega t$.

The 10 provinces with dominant anthropogenic emissions, which peak at February-March (Anhui, Hebei, Henan, Jiangsu, Jiangxi, Shaanxi, Shandong, and Tianjin), exhibit a fairly constant ratio $r$ between amplitude and offset for anthropogenic emissions: $A^{a}=r E_{0}^{a}$, with $r=0.25 \pm 0.08$. Using this relation, and assuming that the fit results for Mongolia and Inner Mongolia are adequately described by Eq. (5), we can separate the natural from the anthropogenic contribution. We find for East Mongolia (i.e. the $53 \%$ within the model domain) an average natural emission of $56 \mathrm{Gg} \mathrm{N} \mathrm{yr}^{-1}$, 

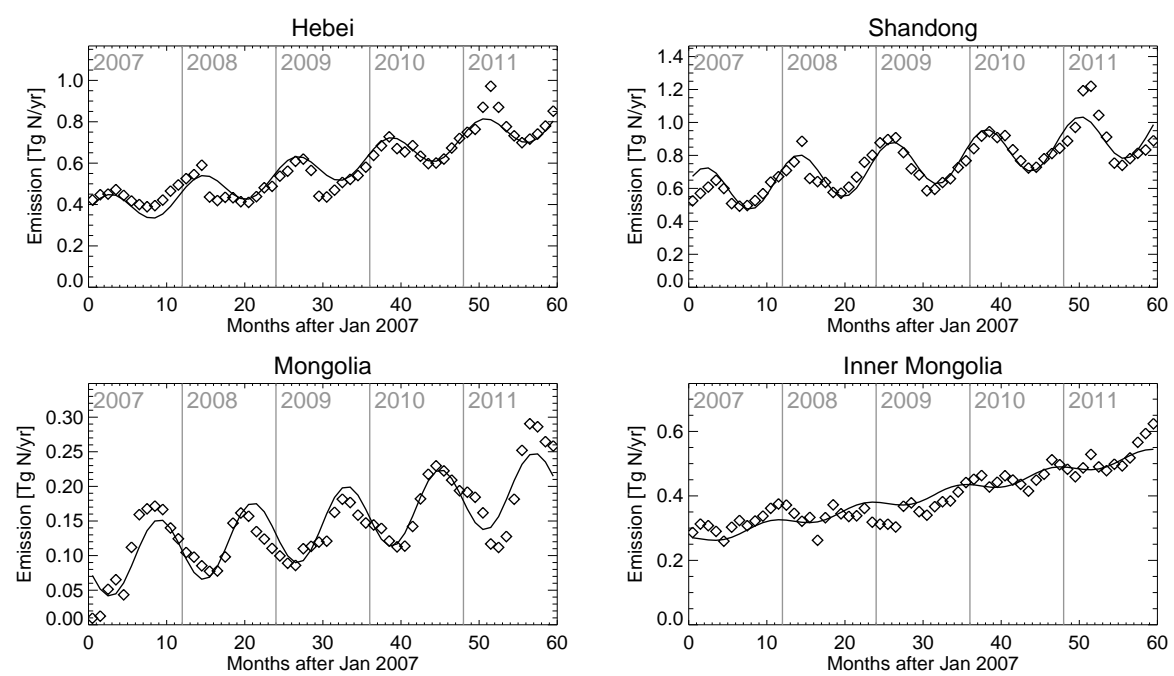

Fig. 4. Emission time series for January 2007 to December 2011 estimated by the DECSO algorithm for different regions. The black line indicates the best fit of the trend model.

and an anthropogenic emission in 2007 of $41 \mathrm{Gg} \mathrm{N} \mathrm{yr}^{-1}$ with an absolute trend of $24 \mathrm{Gg} \mathrm{N} \mathrm{yr}^{-2}$. For Inner Mongolia (i.e. the $83 \%$ within the model domain), we find an average natural emission of $65 \mathrm{Gg} \mathrm{N} \mathrm{yr}^{-1}$, and an anthropogenic emission in 2007 of $222 \mathrm{Gg} \mathrm{N} \mathrm{yr}^{-1}$ with a trend of $55 \mathrm{Gg} \mathrm{N} \mathrm{yr}^{-2}$. The natural emission estimates should be used with caution. The less pronounced seasonality of the dominant power plant emissions might distort the assumed ratio, and can partly explain the lack of seasonal cycle in Inner Mongolia by itself.

\section{Non-local contribution to tropospheric $\mathrm{NO}_{2}$}

In the DECSO algorithm, the relation between the observable tropospheric $\mathrm{NO}_{2}$ column $c$ at footprint $i$ at time $t=T$ and the mean $\mathrm{NO}_{\mathrm{x}}$ emissions $e$ in grid cell $j$ during time interval $(0, T)$ is described as

$c_{i}(T)=b_{i}+\sum_{j=1}^{n} \Psi_{i j} e_{j} \equiv b_{i}+\sum_{j=1}^{n} p_{i j}$

$b_{i}$ represents the part of the $\mathrm{NO}_{2}$ column which has been emitted before this time interval (i.e. having an age larger than $T$ ), and whose relation with emission sources is not accounted for. The summation sums over all $n$ grid cells. Matrix $\Psi$ represents the sensitivity matrix $\mathbf{H}$ from Eq. (1) after interpolating towards the observation footprints and applying the averaging kernel (see Mijling and van der A, 2012). The quantity $p_{i j}=\Psi_{i j} e_{j}$ can be regarded as the partial $\mathrm{NO}_{2}$ column in footprint $i$ due to $\mathrm{NO}_{\mathrm{x}}$ emissions in grid cell $j$ during $(0, T)$. This can be used to study the origin of the tropospheric $\mathrm{NO}_{2}$ observed in a certain region.
The mean observed tropospheric column for a region $R$ from $m$ observations can be written as an weighted average:

$c_{R}=\sum_{i=1}^{m} w_{i} c_{i} \equiv b_{R}+\sum_{j=1}^{n} p_{R, j}$, with $\sum_{i=1}^{m} w_{i}=1$,

in which $w_{i}$ corrects for the fraction of the footprint covering $R\left(w_{i}=0\right.$ if the footprint is completely outside $R$ ). The mean partial column observed in region $R$ originating from emissions in a source region $S$ is obtained by summation over all grid cells associated with $S$ :

$c_{R, S}=\sum_{j \in S} p_{R, j}=\sum_{j \in S} \sum_{i=1}^{n} w_{i} \Psi_{i j} e_{j}$.

We use this relation to study the origin of the tropospheric $\mathrm{NO}_{2}$ over North Korea, South Korea, and Beijing during 2007-2011. To get sufficient sampling of the selected regions (all observations with a cloud fraction larger than $20 \%$ are filtered out), we look at quarterly averages of $\mathrm{NO}_{2}$.

Note that Eq. (8) calculates the direct contribution to region $R$ from source region $S$, i.e. the $\mathrm{NO}_{\mathrm{x}}$ which has been emitted during $(0, T)$ before observation. The time interval corresponds to the times between two satellite overpasses, i.e. $T=24 \mathrm{~h}$. It does not account for $\mathrm{NO}_{\mathrm{x}}$ which has been emitted before this time window, or $\mathrm{NO}_{\mathrm{x}}$ which has been transported in reservoir species such as PAN. Theoretically, based on sensitivity matrices $\mathbf{H}$ from previous periods, the source regions of the background field $b$ could be resolved. This information, however, we have not stored during the processing.

\subsection{North Korea}

As can be seen in Fig. 5, mean emissions in North Korea are small compared to industrialized countries. Emissions are 
high in the first three months, due to an overestimation of the initial emissions by INTEX-B, and the time the DECSO algorithm needs to adjust to the new emission levels. North Korean emission peaks are in summer time, as are the associated concentration maxima. This is characteristic for dominating biogenic soil emissions; see van der A et al. (2008). The total $\mathrm{NO}_{2}$ concentrations, however, usually peak in wintertime, indicating that a significant part of $\mathrm{NO}_{2}$ in the North Korean troposphere is from anthropogenic origin, imported from elsewhere.

Local emissions of $\mathrm{NO}_{\mathrm{x}}$ account for $22 \%$ of the average tropospheric $\mathrm{NO}_{2}$ concentrations in North Korea. The Chinese contribution to the $\mathrm{NO}_{2}$ concentration in North Korea is at least $21 \%$. Due to predominant northwest winds, they originate mainly from emissions in Liaoning province, where the city of Shenyang is a strong source. South Korea contributes at least $7 \%$, mainly originating from the Seoul area, which is located close to the border. Contribution of international shipping accounts for at least $5 \%$. The remaining part $(45 \%)$ of the observed concentrations is mainly a background concentration originating from $\mathrm{NO}_{\mathrm{x}}$ emitted earlier than $24 \mathrm{~h}$ before detection time, corresponding to $b_{R}$ in Eq. (7). Because it is unknown how its origin is distributed over the different source areas, the above-mentioned fractions are lower limit values.

Based on the $9 \mathrm{yr}$ data set of tropospheric $\mathrm{NO}_{2}$ retrievals from SCIAMACHY between 2002 and 2011, Schneider and van der A (2012) find a relative trend of 5-15\% $\mathrm{yr}^{-1}$ over North Korea. Since DECSO gives a trend in emissions in North Korea of only $6 \%$, the concentration trend is most probably due to increased emissions in neighbouring China.

\subsection{South Korea}

$\mathrm{NO}_{\mathrm{x}}$ emissions in South Korea are 8-10 times higher than in North Korea, and have generally maxima in wintertime (apart from 2010). From 2008 onward they show a downward trend of $2.2 \% \mathrm{yr}^{-1}$, related to economic recession. Local emissions contribute at least $68 \%$ to tropospheric $\mathrm{NO}_{2}$. Contributions from China account for only $2 \%$, which is less than in North Korea in both a relative and absolute sense. Winds also transport $\mathrm{NO}_{2}$ from shipping around the peninsula into South Korea, which accounts for at least $7 \%$ of the average tropospheric $\mathrm{NO}_{2}$ concentration.

\subsection{Beijing}

On average, $35 \%$ of its tropospheric $\mathrm{NO}_{2}$ originates from local emissions, and has an age less than $24 \mathrm{~h}$. Because of the relative small size of Beijing, a large part of its $\mathrm{NO}_{2}$ is emitted elsewhere. At least $23 \%$ and $5 \%$ come from its neighbouring provinces Hebei and Tianjin. An overall $12 \%$ of Beijing's $\mathrm{NO}_{2}$ is imported from more remote provinces. The average concentration shows a remarkable dip in summer 2008, related to the air quality measures taken for the
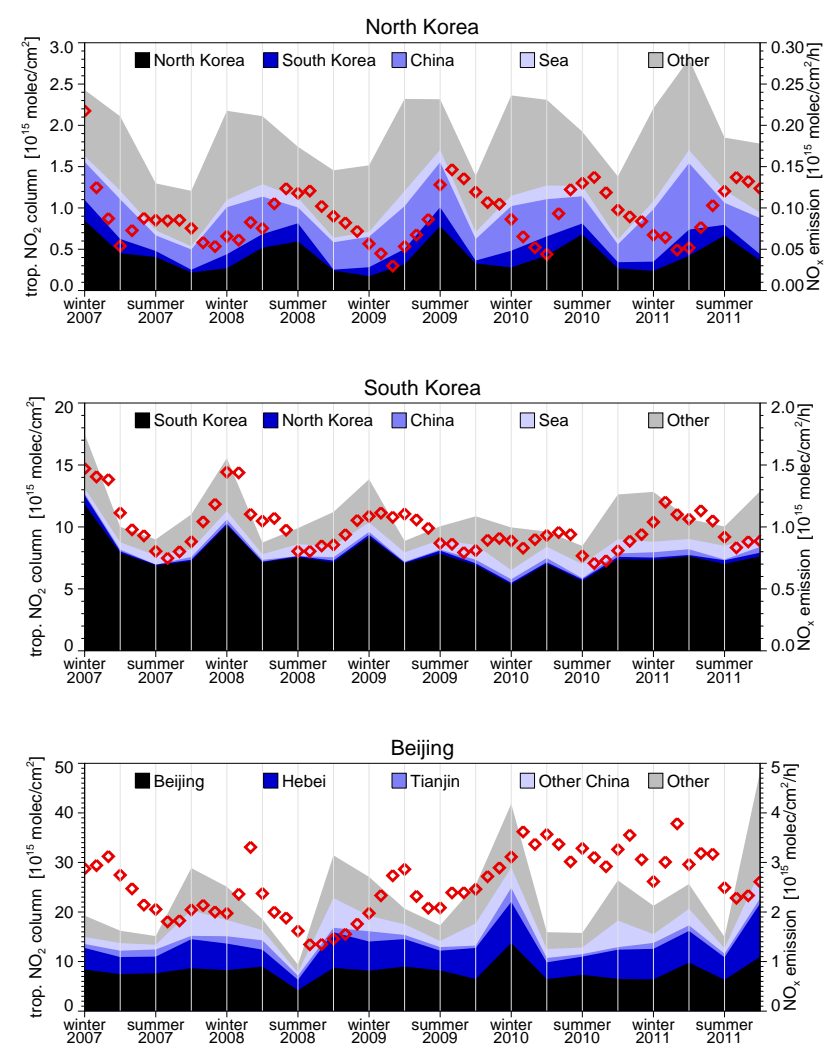

Fig. 5. Mean quarterly tropospheric $\mathrm{NO}_{2}$ concentrations over North Korea, South Korea and Beijing, divided by their origin. In red the monthly emission estimates are shown.

Beijing Olympic Games. Compared with summer 2007, $\mathrm{NO}_{2}$ concentrations dropped $38 \%$. Contributions by local emissions dropped $45 \%$, while $\mathrm{NO}_{2}$ due to emissions in Hebei, Tianjin, and other provinces dropped $38 \%, 42 \%$, and $32 \%$, respectively. Compared to the previous summer, the emissions in Beijing were however reduced by only $19 \%$ (a $7 \%$ reduction in Tianjin, and a $6 \%$ increase in Hebei), showing that an important part of the improvement in air quality (in terms of $\mathrm{NO}_{2}$ ) was also due to favourable meteorological conditions. In the months after the events Beijing emissions start to rise steadily to reach a new record value in April 2011 (127 $\mathrm{Gg} \mathrm{N} \mathrm{yr}^{-1}$ ).

\section{Conclusions}

The DECSO estimates agree well with the bottom-up inventories of EDGAR v4.2 for 2007 and 2008, which gives confidence in the algorithm. However, estimates for 2008 and 2010 are generally lower than in the MEIC inventory. The projected $\mathrm{NO}_{\mathrm{x}}$ emission by REAS v1.1 for 2007-2010 are apparently too low. The DECSO estimates for 2011 are significantly higher for most provinces than the INTEX-B and EDGAR inventories (the DECSO $\mathrm{NO}_{\mathrm{x}}$ emission estimates 
for East China increased by $41 \%$ between 2007 and 2011), showing the need to update emission inventories in China on a regular basis.

Largest $\mathrm{NO}_{\mathrm{x}}$ emitting provinces are clustered in northeast China: Shandong, Hebei, Shaanxi, Jiangsu, followed by Guangdong in south China. All provinces of mainland China show positive trends for 2007-2011, due to the country's economic development. Yearly emission growth rates over $20 \%$ are found in Shaanxi, Hebei, Hainan, Sichuan, and Mongolia.

Probably due to air quality measures and the economic crisis, Japan, South Korea, and Taiwan show a negative relative trend of $5.6 \% \mathrm{yr}^{-1}$ for the Japanese island of Kyushu, $2.2 \% \mathrm{yr}^{-1}$ for South Korea, and $2.1 \% \mathrm{yr}^{-1}$ for Taiwan, taking 2007 as the reference year.

The seasonality of the emissions shows that anthropogenic emissions dominate in most Chinese provinces and peripheral countries. Emissions in Mongolia and Inner Mongolia, however, show a mixed anthropogenic and biogenic signature. The opposite seasonality can be used for a rough estimate of the separate contributions. We find that in 2007, biogenic emissions (mostly by soil) contribute to $58 \%$ and $23 \%$ of the total $\mathrm{NO}_{\mathrm{x}}$ emissions in Mongolia and Inner Mongolia, respectively.

Emissions in North Korea are overestimated by bottomup inventories. The relatively high $\mathrm{NO}_{2}$ concentrations over the country cannot be explained by its own $\mathrm{NO}_{\mathrm{x}}$ emissions. A significant part originates from emissions in China and South Korea. The North Korean situation is a showcase of crossboundary air pollution, and shows the importance of taking into account the transport of trace gases in emission estimate algorithms studies.

$\mathrm{NO}_{2}$ concentrations in South Korea are largely produced locally on land, although at least $7 \%$ originates from emissions at sea by ships.

Although Beijing produces large $\mathrm{NO}_{\mathrm{x}}$ emission by itself, at least $22 \%$ and $5 \%$ of the $\mathrm{NO}_{2}$ concentration comes from neighbouring provinces Hebei and Tianjin. During the summer of the 2008 Olympic Games, the mean $\mathrm{NO}_{2}$ concentration over Beijing was reduced by $38 \%$ with respect to the summer of 2007. The emissions in Beijing were however reduced by $19 \%$, showing that an important part of the improvement in air quality (in terms of $\mathrm{NO}_{2}$ ) was also due to favourable meteorological conditions.

Acknowledgements. This research has been funded by the GlobEmission project, part of the Data User Element programme of the European Space Agency.

Edited by: I. Aben

\section{References}

Bessagnet, B., Hodzic, A., Vautard, R., Beekmann, M., Cheinet, S., Honoré, C., Liousse, C., and L. Rouill: Aerosol modeling with CHIMERE - preliminary evaluation at the continental scale, Atmos. Environ., 38, 2803-2817, 2004.

Boersma, K. F., Eskes, H. J., Dirksen, R. J., van der A, R. J., Veefkind, J. P., Stammes, P., Huijnen, V., Kleipool, Q. L., Sneep, M., Claas, J., Leitao, J., Richter, A., Zhou, Y., and Brunner, D.: An improved tropospheric $\mathrm{NO}_{2}$ column retrieval algorithm for the Ozone Monitoring Instrument, Atmos. Meas. Tech., 4, 19051928, doi:10.5194/amt-4-1905-2011, 2011.

Chen, X. and Zhao, J.: Bidding to drive, Car license auction policy in Shanghai and its public acceptance, Transp. Policy, 27, 39-52, doi:10.1016/j.tranpol.2012.11.016, 2013.

EC-JRC/PBL: Emission Database for Global Atmospheric Research (EDGAR), release version 4.2. European Commission, Joint Research Centre (JRC)/Netherlands Environmental Assessment Agency (PBL), http://edgar.jrc.ec.europa.eu., 2011.

Irie, H., Boersma, K. F., Kanaya, Y., Takashima, H., Pan, X., and Wang, Z. F.: Quantitative bias estimates for tropospheric NO2 columns retrieved from SCIAMACHY, OMI, and GOME-2 using a common standard for East Asia, Atmos. Meas. Tech., 5, 2403-2411, doi:10.5194/amt-5-2403-2012, 2012.

Iwasaki, H. and Nii, T.: The break in the Mongolian rainy season and its relation to the stationary Rossby wave along the Asian jet, J. Climate, 19, 3394-3405, 2005.

Huijnen, V., Eskes, H. J., Poupkou, A., Elbern, H., Boersma, K. F., Foret, G., Sofiev, M., Valdebenito, A., Flemming, J., Stein, O., Gross, A., Robertson, L., D’Isidoro, M., Kioutsioukis, I., Friese, E., Amstrup, B., Bergstrom, R., Strunk, A., Vira, J., Zyryanov, D., Maurizi, A., Melas, D., Peuch, V.-H., and Zerefos, C.: Comparison of $\mathrm{OMI} \mathrm{NO} 2$ tropospheric columns with an ensemble of global and European regional air quality models, Atmos. Chem. Phys., 10, 3273-3296, doi:10.5194/acp-10-3273-2010, 2010.

Koelemeijer, R., Stammes, P., Hovenier, J., and de Haan, J.: A fast method for retrieval of cloud parameters using oxygen A band measurements from the global ozone monitoring experiment, J. Geophys. Res., 106, 3475-3490, 2001.

Li, C., Zhang, Q., Krotkov, N. A., Streets, D. G., He, K., Tsay, S.-C., and Gleason, J. F.: Recent large reduction in sulfur dioxide emissions from Chinese power plants observed by the Ozone Monitoring Instrument, Geophys. Res. Lett., 37, L08807, doi:10.1029/2010GL042594, 2010.

Lin, J.-T., McElroy, M. B., and Boersma, K. F.: Constraint of anthropogenic $\mathrm{NO}_{\mathrm{x}}$ emissions in China from different sectors: a new methodology using multiple satellite retrievals, Atmos. Chem. Phys., 10, 63-78, doi:10.5194/acp-10-63-2010, 2010.

Lin, J.-T., Nielsen, C. P., Zhao, Y., Lei, Y., Liu, Y., and McElroy, M. B.: Recent Changes in Particulate Air Pollution over China Observed from Space and the Ground, Effectiveness of Emission Control, Environ. Sci. Technol., 44 7771-7776, doi:10.1021/es101094t, 2010a.

Lin, J.-T. and McElroy, M. B.: Detection from space of a reduction in anthropogenic emissions of nitrogen oxides during the Chinese economic downturn, Atmos. Chem. Phys., 11, 8171-8188, doi:10.5194/acp-11-8171-2011, 2011.

Lin, J.-T.: Satellite constraint for emissions of nitrogen oxides from anthropogenic, lightning and soil sources over East China on 
a high-resolution grid, Atmos. Chem. Phys., 12, 2881-2898, doi:10.5194/acp-12-2881-2012, 2012a.

Lin, J.-T., Liu, Z., Zhang, Q., Liu, H., Mao, J., and Zhuang, G.: Modeling uncertainties for tropospheric nitrogen dioxide columns affecting satellite-based inverse modeling of nitrogen oxides emissions, Atmos. Chem. Phys., 12, 12255-12275, doi:10.5194/acp-12-12255-2012, 2012b.

Martin, R., Jacob, D., Chance, K., Kurosu, T., Palmer, P., and Evans, M.: Global inventory of nitrogen oxide emissions constrained by space-based observations of $\mathrm{NO}_{2}$ columns, J. Geophys. Res., 108, 4537, doi:10.1029/2003JD003453, 2003.

Mijling, B., van der A, R. J., Boersma, K. F., Van Roozendael, M., De Smedt, I., and Kelder, H. M.: Reduction of $\mathrm{NO}_{2}$ detected from space during the 2008 Beijing Olympic Games, Geophys. Res. Lett., 36, L13801, doi:10.1029/2009GL038943, 2009.

Mijling, B. and van der A, R. J.: Using daily satellite observations to estimate emissions of short-lived air pollutants on a mesoscopic scale, J. Geophys. Res., 117, D17302, doi:10.1029/2012JD017817, 2012.

Ohara, T., Akimoto, H., Kurokawa, J., Horii, N., Yamaji, K., Yan, X., and Hayasaka, T.: An Asian emission inventory of anthropogenic emission sources for the period 1980-2020, Atmos. Chem. Phys., 7, 4419-4444, doi:10.5194/acp-7-4419-2007, 2007.

Schmidt, H., Derognat, C., Vautard, R., and Beekmann, M.: A comparison of simulated and observed ozone mixing ratios for the summer of 1998 in Western Europe, Atmos. Environ. 36, 62776297, 2001.

Schneider, P. and van der A, R. J.: A global single-sensor analysis of 2002-2011 tropospheric nitrogen dioxide trends observed from space, J. Geophys. Res., 117, D16309, doi:10.1029/2012JD017571, 2012.

Stavrakou, T., Müller, J., Boersma, K., De Smedt, I., and van der A, R.: Assessing the distribution and growth rates of $\mathrm{NO}_{\mathrm{x}}$ emission sources by inverting a 10 year record of $\mathrm{NO}_{2}$ satellite columns, Geop hys. Res. Lett., 35, L10801, doi:10.1029/2008GL033521, 2008. van $\operatorname{der}$ A, R. J., Peters, D. H. M. U., Eskes, H. J., Boersma, K. F., Van Roozendael, M., De Smedt, I. and Kelder, H. M.: Detection of the trend and seasonal variation in tropospheric $\mathrm{NO}_{2}$ over China, J. Geophys. Res., , 111, D12317, doi:10.1029/2005JD006594, 2006.

van $\operatorname{der}$ A, R. J., Eskes, H. J., Boersma, K. F., van Noije, T. P. C., Van Roozendael, M., De Smedt, I., Peters, D. H. M. U., Kuenen, J. J. P., and Meijer, E. W.: Trends, seasonal variability and dominant $\mathrm{NO}_{\mathrm{x}}$ source derived from a ten year record of $\mathrm{NO}_{2}$ measured from space, J. Geophys. Res., 113, D04302, doi:10.1029/2007JD009021, 2008.

Wang, S. W., Zhang, Q., Streets, D. G., He, K. B., Martin, R. V., Lamsal, L. N., Chen, D., Lei, Y., and Lu, Z.: Growth in $\mathrm{NO}_{\mathrm{x}}$ emissions from power plants in China: bottom-up estimates and satellite observations, Atmos. Chem. Phys., 12, 4429-4447, doi:10.5194/acp-12-4429-2012, 2012.

Zhang, Q. S. D., He, K., Wang, Y., Richter, A., Burrows, J., Uno, I., Jang, C., Chen, D., Yao, Z., and Lei, Y.: $\mathrm{NO}_{\mathrm{X}}$ emission trends for China, 1995-2004: The view from the ground and the view from space, J. Geophys. Res., 112, D22306, doi:10.1029/2007JD008684, 2007.

Zhang, Q., Streets, D. G., Carmichael, G. R., He, K. B., Huo, H., Kannari, A., Klimont, Z., Park, I. S., Reddy, S., Fu, J. S., Chen, D., Duan, L., Lei, Y., Wang, L. T., and Yao, Z. L.: Asian emissions in 2006 for the NASA INTEX-B mission, Atmos. Chem. Phys., 9, 5131-5153, doi:10.5194/acp-9-5131-2009, 2009a.

Zhang, Q., Streets, D. G., He, K.: Satellite observations of recent power plant construction in Inner Mongolia, China, Geophys. Res. Lett., 36, L15809, doi:10.1029/2009GL038984, 2009 b. 